lens, that of total internal reflexion seems to provide a reasonable preliminary hypothesis.

\section{K. Tansley}

Institute of Ophthalmology, London, W.C.I.

B. K. Johnson

Imperial College of Science and Technology, London, S.W.7. Sept. 28.

${ }^{1}$ Denton, E. J., and Pirenne, M. H., J. Physiol., 116, 33P (1952). ${ }^{2}$ Wright, W. D., and Nelson, J. H., Proc. Phys. Soc., 48, 401 (1936). ${ }^{3}$ O'Brien, B., J. Opt. Soc. Amer., 41, 882 (1951).

\section{Survival of the Heart following Deep Hypothermia}

DEEP hypothermia of warm-blooded animals favours the survival of their organs. For example, in the rat at normal body-temperature the heart ceases to beat several minutes after opening the chest, whereas in the rat cooled to $15^{\circ} \mathrm{C}$. by the closed-vessel technique cardiac contractions can be seen approximately $l \mathrm{hr}$. after respiratory arrest ${ }^{1}$. The intestine removed from a hypothermic dog contracts spontaneously when re-warmed and retains this property longer than an intestine isolated from a normothermic $\operatorname{dog}^{2}$. We have shown that the heart continues to beat for a much longer period after opening the thorax in rats which have been severely chilled and then re-warmed to normal bodytemperature than in rats at the same temperature which had not been previously chilled ${ }^{3}$.

The effect of profound hypothermia is shown equally well by survival of the heart after functional arrest. This is illustrated by the experiments to be described here.

When rats at normal body-temperature are killed by destroying the medulla and opening the chest, their hearts cease to beat after several minutes. If the bodies are then placed in the refrigerator at 6-9 ${ }^{\circ} \mathrm{C}$., cardiac contractions can be induced 6-12 hr. later in about half the animals by pouring Ringer's solution at $38-40^{\circ} \mathrm{C}$. directly on to their hearts. Even after $48 \mathrm{hr}$. this technique sometimes elicits weak signs of activity around the orifices of the great veins.

Much more striking results are obtained if the rats are in a state of deep hypothermia when killed. Rats cooled by the closed-vessel technique ${ }^{4}$ to bodytemperatures between $13^{\circ}$ and $16^{\circ} \mathrm{C}$. were killed as described above and put with open thoraces in the refrigerator at $6-9^{\circ} \mathrm{C}$. At this temperature the heart soon stops beating. Next day and on subsequent days the hearts are re-warmed by pouring over them Ringer's solution at $38-40^{\circ} \mathrm{C}$. As a result, ventricular contractions are frequently seen several days after death, while rhythmic movements near the openings of the great veins have actually been seen when the corpses had been kept at $6-9^{\circ} \mathrm{C}$. for as long as eighteen days.

Re-warming the heart for several moments daily by our method seems to prolong the functional survival which we have just described. We also noticed that this phenomenon is more regularly seen in exsanguinated hearts.

It is known that, in rats cooled to the point of freezing or even below, cardiac activity can be completely ro-established approximately one hour after cessation. of breathing and circulation ${ }^{5}$. Certain manifestations of myocardial activity can, as we have just seen, be observed many days after death provided that the rat was killed in deep hypothermia and the corpse stored at a low temperature.

The point is not, of course, that there is a genuine re-establishment of the functions of the heart, but only that there are a few signs of activity of the myocardium. Our results nevertheless indicate that deep hypothermia before death is favourable for survival of the myocardium. It might also be an advantage when transplanting or culturing organs and tissues from homœotherms to remove them from animals in deep hypothermia.

$$
\begin{aligned}
& \text { J. Glaja } \\
& \text { J. Radulović }
\end{aligned}
$$

Institut de Physiologie de la Faculté des Sciences, Université de Belgrade.

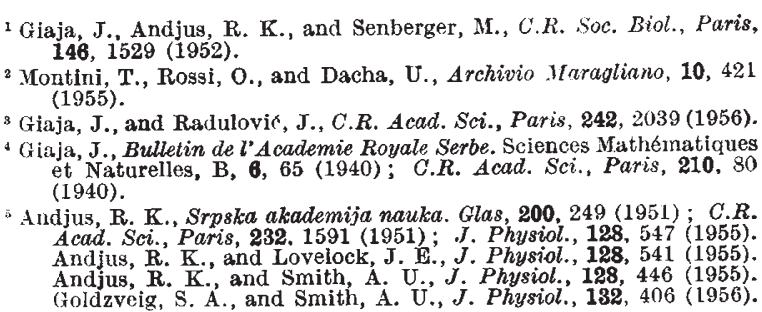

\section{Effect of Surface-active Agents on the Living Cell}

IT was observed some time ago ${ }^{1}$ that treatment with surface-active agents influences the freshness and the keeping qualities of picked fruit and the development of cut flowers. When freshly picked fruit were sprayed with a dilute $(0 \cdot 01-0 \cdot 1$ per cent) solution of a surface-active substance the fruit kept about twice as long as the controls. It has also been demonstrated that similarly treated buds of freshly picked flowers can be forced to open prematurely.

Experiments have been carried out on the action of such compounds on living plants. Undiluted non-ionic surface-active agents were used, as earlier investigations seem to indicate that little effect can be obtained with dilute solutions.

Twelve bare twigs on a shrub of mock orange (Philadelphus coronarius) were painted with 'Tweon 40 ' (polyoxyethylene sorbitan-mono-palmitate) at the beginning of August ; on six of the twigs the treatment was repeated twice at intervals of one week. On the twigs which had been treated only once, the first green buds appeared six weeks later, 12-14 days before they did on any of the untreated branches. The twigs which had been treated three times remained bare throughout the summer.

On a red flowering rosebush three small rosebuds were painted with 'Triton $X$ 100' (alkylated aryl poly-ether alcohol). Three days later the buds started to open, although they were only half the size of the buds which open under normal conditions. 'ihe flowers were distorted; their petals nearly colourless. 'This distortion was also observed when the exporiment, was repeated using other surface-active substances.

Four Hibiscus buds were painted with $G$ 8916-P (polyoxyethylene-sorbitan esters of mixed fatty and resin acids). The buds started to open two days after the treatment, five days before the control buds which were at the same stage of development. In 